\title{
Pengaruh Tanggung Jawab dan Loyalitas Kerja Terhadap Kinerja Karyawan Pada Wisma Grand Kemala Palembang
}

\author{
Akila \\ Manajemen, F. Ekonomi dan Bisnis, Univ. PGRI Palembang, akilaali62@gmail.com
}

\begin{abstract}
ABSTRAK
Penelitian ini bertujuan untuk mengetahui pengaruh tanggungjawab dan loyalitas kerja terhadap kinerja karyawan pada Wisma Grand Kemala Palembang. Populasi dari penelitian ini adalah seluruh karyawan pada Wisma Grand Kemala Palembang sebanyak 34 orang. Pengambilan sampel dari penelitian ini teknik sampling jenuh. Tehknik pengumpulan data dalam penulisan ini yaitu kuesioner atau Angket. Teknik analisis data yang digunakan adalah analisis regresi linier berganda, analisis korelasi berganda, analisis koefisien determinasi, dengan pengujian hipotesis uji $t$ dan uji $F$ dengan bantuan software SPSS 22 forwindows. Hasil penelitian ini menunjukkan bahwa 1) Secara simultan terdapat pengaruh tanggung jawab dan loyalitas terhadap kinerja karyawan pada Wisma Grand Kemala Palembang, 2) Secara parsial terdapat pengaruh tanggung jawan terhadap kinerja karyawan pada Wisma Grand Kemala Palembang, 3) Secara parsial juga ada pengaruh loyalitas kerja terhadap kinerja karyawan pada Wisma Grand KemalaPalembang.
\end{abstract}

Kata Kunci : Tanggung jawab, loyalitas, dan Kinerja

\section{ABSTRACT}

This study aims to determine the effect of work responsibilities and loyalty on employee performance at Wisma Grand Kemala Palembang. The population of this study were all employees at Wisma Grand Kemala Palembang as many as 34 people. Sampling from this study was a saturated sampling technique. Data collection techniques in this writing are questionnaire or Questionnaire. Data analysis techniques used are multiple linear regression analysis, multiple correlation analysis, coefficient of determination analysis, by testing the hypothesis of the $t$ test and F test with the help of SPSS 22 software for windows. The results of this study indicate that 1) Simultaneously there is an influence of responsibility and loyalty on employee performance at Wisma Grand Kemala Palembang, 2) Partially there is an influence of responsibility on employee performance at Wisma Grand Kemala Palembang, 3) Partially there is also the influence of work loyalty on employee performance at Wisma Grand Kemala Palembang.

Keywords: Responsibility, loyalty, and performance

\section{A. PENDAHULUAN}

Majunya suatu perusahaan atau organisasi tergantung pada sumber daya manusia yang mengelolanya, baik pemerintah maupun swasta dan masyarakat. Kinerja yang tinggi sangat diinginkan bagi setiap organisasi atau perusahaan karena kinerja merupakan tolak ukur untuk membandingkan hasil yang diharapkan dengan sebuah pekerjaan atau jabatan yang telah dipercaya kepada seseorang. Mangkunegara (2016:3), istilah kinerja berasal dari kata job performance yaitu hasil kerja yang ingin diraih atau dicapai oleh individu maupun kelompok. Kinerja merupakan prestasi kerja atau hasil kerja baik kualitas maupun kuantitas yang dicapai karyawan persatuan periode.

Untuk mencapai tujuan sebuah organisasi atau perusahaan, maka peran karyawan merupakan faktor yang penting. Selain waktu, tenaga dan kemampuan benar-benar harus dimanfaatkan secara efesien dan 
efektif bagi kepentingan organisasi atau perusahaan tersebut. Efisien dan efektivitas kerja karyawan sebagai sumber daya manusia dalam suatu perusahaan sangat penting bagi peningkatan hasil kerja dilingkungan perusahaan. Karena keberhasilan perusahaan dilihat dari kerja karyawan mencerminkan bertangung jawab penuh terhadap tugas-tugas yang diberikan oleh perusahaan. Disisi lain tujuan peningkatan kinerja karyawan akan membawa kemajuan sebuah perusahaan.

Kinerja merupakan pencapaian yang optimal sesuai dengan potensi yang dimiliki oleh seorang pegawai. Kinerja ini menggambarkan sejauh mana seseorang dalam menjalankan tugas dan berusaha untuk mencapai tujuannya (Oktariansyah, 2020). Oleh sebab itu upaya untuk meningkatkan hasil kerja karyawan penting untuk diperhatikan oleh perusahaan dalam mencapai tujuan dan kelangsungan perusahaan itu karena tergantung pada hasil kerja karyawan didalamnya.

Faktor lain yang sangat berpengaruh kinerja karyawan adalah loyalitas kerja karyawan itu sendiri, setiap perusahaan menginginkan karyawan yang memiliki loyalitas atau kesetian yang tinggi dalam melaksanakan pekerjaan. Untuk meningkatkan loyalitas kerja itu tidak mudah, karena loyalitas kerja merupakan sikap kesetiaan mental yang ditujukan pada perusahaan. Rasimin dan Pranita (2016:2) Loyalitas kerja merupakan sebuah pengabdian, kepercayaan dan juga kesetiaan yang diberikan kepada individu atau sebuah instansi, dengan penuh tanggung jawab dan selalu berperilaku baik. Karyawan yang loyal akan sangat dihargai oleh perusahaan karena perusahaan sangat membutuhkannya untuk menentukan maju atau mundurnya perusahaan dimasa yang akan datang. Sikap belum rasa memiliki kesetiaan terhadap perusahaan, misalkan peraturan yang memberikan pelayanan terbaik masih belum sepenunya dilakansakan oleh karyawan memberikan pelayanan terbaik. Hai ini perlu mendapat perhatian sedini mungkin sehingga hasil yang diinginkan perusahaan tercapai untuk tujuan.

Adapun salah satu faktor selain loyalitas yang mempengaruhi kinerja tuwujudnya kemajuan perusahaan adalah tanggung jawab terhadap pekerjaan. Hasibuan (2016:70) tanggung jawab adalah keharusan untuk melakukan semua kewajiban atau tugas-tugas yang dibebankan kepadanya sebagai akibat dari wewenang yang diterima atau dimilikinya. Tanggung jawab terhadap pekerjaan sangatlah penting dalam sebuah organisasi atau perusahaan untuk mencapai hasil diharapkan. Dalam pelaksanaan masih ada karyawan yang merasa ketidak sesuaian terhadap hasil dari apa yang diharapkannya, hal tersebut timbul kurangnya tanggungjawab terhadap pekerjaan. Sehingga tingkat pencapaian hasil kerja yang ingin dicapai oleh perusahaan belum maksimal atau belum tercapai.

\section{B. KAJIAN TEORI}

\section{1) Pengertian Tanggung Jawab}

Tanggung jawab dalam arti yang harus memikul beban kewajiban yang harus dilakukan dalam setiap individu. Tanggung jawab berhubungan dengan kualitas untuk bertanggung jawab secara moral, hukum dan mental. Hasibuan (2014:70) Tanggung jawab adalah keharusan untuk melakukan semua tanggung jawab/tugas-tugas yang dibebankan sebagai akibatdari wewenang yang diterima atau dimilikinya. Yusuf (2017:79) bertanggung jawab dalam bekerja 
adalah sesuatu yang sangat urgen dalam kehidupan seorang muslim. Setiap pekerja wajib bertanggung jawab bukan hanya kepada atasan, tetapi lebih dari itu kepada Allah. Dari pendapat-pendapat tersebut diatas dapat disimpulkan oleh peneliti bahwa tanggung jawab suatu pekerjaan merupakan kewajiban yang harus dilakukan dalam setiapindividu.

\section{2) Indikator Tanggung Jawab}

Prayogo dan Fahmi (2013:297) indicator - indikator keberhasilan tanggung jawab sosial perusahaan ada empat sebagai berikut;

a. Secara umum, keberhasilan tanggung jawab sosial dapat dilihat dari capaian nilai etika yang dikandungannya yaitu turut menegakkan social justice, sustaiinability dan eguity.

b. Secara sosial, keberhasilan tanggung jawab sosial dapat dilihat dari tinggi rendahnya legetimasi sosial korporasi di hadapan stakeholder sosialnya.

c. Secara bisnis, keberhasil tanggung jawab sosial dapat dilihat dari meningkatnya nilai saham akibat peningkatan corporate social image.

d. Secara teknis, keberhasilan tanggung jawab sosial dapat dilihat dari capaian program hasil evaluasi teknik lapangan.

\section{3) Loyalitas Kerja}

Hasibuan dan Soegandhi dkk (2013:3) mengemukakan bahwa Loyalitas kerja atau kesetiaan kerja adalah salah satu unsur yang digunakan dalam penilaian pegawai yang mencakup kesetiaan terhadap pekerjaannya, jabatannya dan organisasi. Kesetiaan ini dicerminkan oleh kesediaan pegawai menjaga dan membela organisasi didalam maupun diluar pekerjaan dari rongrongan orang yang tidak bertanggungjawab.

Richheld dan Soegandhi dkk (2013:3) menyatakan bahwa semakin tinggi loyalitas pegawai di suatu organisasi, maka semakin mudah bagi organisasi itu untuk mencapai tujuantujuan organisasi yang telah ditetapkan sebelumnya oleh pemilik organisasi. Sebaliknya, bagiorganisasi yang loyalitas para pegawainya rendah, akan sulit bagi organisasi tersebut untuk mencapai tujuan-tujuan organisasinya yang telah ditetapkan sebelumnya oleh para pemilik organisasi.

Dari pendapat-pendapat tersebut diatas dapat disimpulkan oleh peneliti bahwa loyalitas kerja merupakan unsur penilaian yang meliputi kesetiaan terhadap pekerjaan, jabatan dan organisasi. karyawan yang memiliki loyalitas tinggi akan melakukan tugas seoptimal mungkin untuk menghasilkan yang terbaik bagi organisasinya atau perusahaan.

\section{4) Indikator-indikator Loyalitas}

Soegandhi dkk (2013:3) aspekaspek loyalitas kerja yang terdapat pada individu yang menitik beratkan pada pelaksanaan kerja yang dilakukan pegawai yaitu sebagai berikut:

a. Taat pada peraturan

Peraturan yang diterapkan untuk memperlancar dan harus ditaati dan dilaksanakan dengan baik, maka akan menimbulkan kedisiplinan yang menguntungkan instansi baik secara intern maupun ekstern.

b. Tanggung jawab pada
perusahaan
Kesanggupan pegawai untuk
melaksanakan tugasnya akan
memberikan keberanian dan
kesadaran bertanggungjawab
terhadap resiko atas tugas apa
yang telah dilaksanakan.


c. Kemauan untuk bekerjasama

Bekerjasama dengan orangorang dalam suatu kelompok akan memungkinkan perusahaan dapat mencapai tujuan yang tidak mungkin dicapai oleh orangorang secara individu.

d. Rasa memiliki

Rasa ingin memiliki terhadap perusahaan akan membuat pegawai memiliki sikap untuk ikut menjaga dan bertanggung jawab terhadap perusahaan sehingga akan menimbulkan loyalitas untuk mencapai tujuanperusahaan.

e. Hubungan antar pribadi

Pegawai yang mempunyai loyalitas kerja tinggi akan mempunyai sikap fleksibel ke arah tata hubungan antara pribadi.

f. Kesukaan terhadappekerjaan

Kesukaan terhadap pekerjaan dari diri individu dapat dilihat dari keunggulan pegawai dalam bekerja, dan pegawai tidak pernah menuntut apa yang diterimanya diluar gaji pokok.

\section{5) Kinerja}

Fahmi (2016:226), Kinerja merupakan hasil yang diperoleh oleh suatu organisasi baik organisasi bersifat profit oriented dan non profit oriented yang dihasilkan selama satu periode waktu.

Wibowo (2015:4), Kinerja merupakan implementasi dari rencana yang telah disusun tersebut. Implementasi kinerja dilakukan oleh sumber daya manusia yang memiliki kemampuan, kompetensi, motivasi, dan kepentingan.

Prawirosentono dan Sinambela (2016:481), Kinerja adalah hasil kerja yang dapat dicapai oleh seseorang atau sekelompok orang dalam suatu organisasi, sesuai dengan wewenang dan tanggung jawab masing-masing, dalam rangka upaya mencapai tujuan organisasi bersangkutan secara legal, tidak melanggar hukum dan sesuai dengan moral dan etika.

Sinambela (2016:483) Kinerja adalah kesediaan seseorang atau kelompok untuk melakukan suatu kegiatan dan menyempurnakannya sesuai dengan tanggung jawabnya dengan hasil seperti yang diharapkan.

Dapat disimpulkan bahwa kinerja merupakan tingkat pencapaian atau hasil kerja seseorang dari sasaran yang harus dicapai atau tugas yang harus dilaksanakan sesuai dengan tanggung jawab masing-masing dalam periode tertentu.

\section{6) Faktor yang Mempengaruhi Kinerja Pegawai}

Sedarmayanti dalam Widodo (2015:133) faktor-faktor yang mempengaruhi kinerja pegawai sebagai berikut:

$\checkmark \quad$ Sikap dan mental (motivasi kerja, disiplin kerja, dan etika kerja)

$\checkmark$ Pendidikan

$\checkmark \quad$ Keterampilan

$\checkmark \quad$ Manajemen Kepemimpinan

$\checkmark \quad$ Tingkat penghasilan

$\checkmark \quad$ Gaji dan kesehatan

$\checkmark$ Jaminan sosial

$\checkmark \quad$ Sarana dan prasarana

$\checkmark$ Teknologi dan,

$\checkmark \quad$ Kesempatan berprestasi

\section{7) Indikator Kinerja Pegawai}

Wibowo (2014:101) Indikator kinerja adalah sebagai berikut:

1) Tujuan, merupakan keadaan yang berbeda yang secara aktif dicari oleh seorang individu atau seorang organisasi untuk dicapai. Tujuan merupakan sesuatu keadaan yang lebih baik yang ingin dicapai kemasa yang akan datang.

2) Standar, mempunyai arti penting 
karena memberitahukan kapan suatu tujuan dapat diselesaiskan. Standar merupakan suatu ukuran apakah tujuan yang diinginkan dapat dicapai.

3) Umpan Balik, melaporkan kemajuan, baik kualitas maupun kuantitas dalam mencapai tujuan yang didefinisikan dalam standar. Umpan balik merupakan masukan yang dipergunakan untuk mengukur kemajuan kinerja, standar kinerja, dan percapaian tujuan.

4) Alat atau Sarana, merupakan sumber daya yang dapat digunakan untuk membantu menyelesaikan tujuan yang sukses. Alat atau sarana merupakan faktor penunjang untuk percapaiantujuan.

5) Kompetensi, merupakan persyaratan utama dalam kinerja. Kompetensi merupakan kemampuan yang dimiliki seseorang untuk menjalankan pekerjaan yang diberikan kepadanya dengan baik. Orang harus melakukan lebih dari sekedar belajar tentang sesuatu, harus dapat melakukan pekerjaannya dengan baik.

6) Motif, merupakan alat pendorong bagi seseorang untuk melakukan sesuatu.

7) Peluang, Pekerja perlu mendapatkan pekerjaan untuk menunjukkan prestasi kerjanya.

\section{METODE PENELITIAN}

1) Variabel Penelitian

Variabel penelitian merupakan suatu atribut atau sifat atau nilai dari orang, objek, kegiatan yang mempunyai variasi tertentu yang ditetapkan oleh peneliti dan kemudian ditarik kesimpulannya. Sugiyono (2018:96). Variabel dalam penelitian ini terdiri dari dua variabel yaitu variabel bebas dan variabel terikat. Variabel bebas (variabel independen) merupakan variabel yang mempengaruhi atau yang menjadi sebab perubahannya atau timbulnya variabel dependen (terikat). Variabel bebas $(X 1)$ dalam penelitian ini terdiri dari tanggung jawab (X1) dan loyalitas kerja (X2). Variabel Terikat ( Variabel Dependen) merupakan variabel yang dipengaruhi atau yang menjadi akibat, karena adanya variabel bebas. Variabel terikat $(Y)$ dalam penelitian ini adalah Kinerja $(Y)$.

\section{2) Defenisi Operasional}

a) Tanggung Jawab

Tanggung jawab adalah keharusan untuk melakukan semua kewajiban atau tugas- tugas yang dibebankan kepadanya sebagai akibat dari wewenang yang diterima atau dimiliki. (Hasibuan, 2016:70). Dengan indikator yang ditetapkan dalam penelitian ini adalah nilai etika yaitu justice, sustainability, dan equity, seraca sosial, tinggi rendahnya legistimasi sosial korporasi dihadapan stakeholder sosialnya, secara bisnis.

\section{b) Loyalitas Kerja}

Loyalitas kerja atau kesetiaan kerja adalah salah satu unsur yang digunakan dalam penilaian pegawai yang mencakup kesetiaan terhadap pekerjaannya, jabatannya dan organisasi. Hasibuan dan Soegandhi (2014:3). Dengan Indikator yang digunakan adalah Taat pada peraturan, Tanggung jawab pada perusahaan, Kemauan untuk bekerja sama, Rasa memiliki, Hubungan antar pribadi, Kesukaan terhadap pekerjaan

c) Kinerja

Kinerja merupakan implementasi dari rencana yang telah disusun tersebut. Implementasi kinerja dilakukan oleh sumber daya manusia 
yang memiliki kemampuan, kompetensi, motivasi, dan kepentingan. Wibowo (2014:4) Indikator dalam penelitian ini adalah Tujuan, Standar, Umpan Balik, Alat atau sarana, Kompetensi, Motif, Peluang.

\section{3) Populasi dan Sampel}

Sujarweni (2019:80) populasi adalah keseluruhan jumlah yang terdiri atas objek atau subjek yang mempunyai karakteristik dan kualitas tertentu yang ditetapkan oleh peneliti dan dipelajari kemudian ditarik kesimpulannya. Populasi dari penelitian ini adalah seluruh karyawan Wisma Grand Kemala Palembang berjumalah 34 orang. Pengambilan sampel dari penelitian ini teknik sampling jenuh. Sampling jenuh adalah teknik penentuan sampel bila semua anggota digunakan sebagai sampel. Istilah lain sampel jenuh adalah sensus, dimana dimana semua anggota populasi dijadikan sampel. Untuk sumber data yang di peroleh data primer adalah data yang diperoleh dari responden melalui kusioner, kelompok fokus, dan planel, atau juga data hasil wawancara peneliti dengan nara sumber. Data yang diperoleh dari data primer ini harus diolah lagi. Sumber data yang langsung memberikan data kepada pengumpul data. Untuk data sekunder merupakan data yang didapat dari cacatan, buku, dan artikel, buku-buku teori, majalah dan sebagainya. Data yang diperoleh dari data sekunder ini tidak perlu diolah lagi. Sumber yang tidak langsung memberikan data pada pengumpul data.

\section{4) Tehknik Pengumpulan Data}

Tehknik pengumpulan data dalam penulisan ini yaitu kuesioner atau Angket (Questionairre). Sujarweni (2019:94) kuesioner merupakan teknik pengumpulan data yang dilakukan dengan cara memberi seperangkat pentanyaan atau pernyataan tertulis kepada para responden untuk dijawab.

\section{5) Teknik Uji Coba Instrumen}

Penulis dalam penelitian menggunakan teknik uji instrumen meliputi uji validitas dan reliabilitas. Sujarweni (2019:165) menjelaskan bahwa uji validitas adalah alatal analisis yang digunakan untuk mengukur valid atau tidak suatu pertanyaan / kusioner. Kusioner / pertanyaan dikatakan sah atau valid jika pertanyaan pada kusioner tersebut mampu mengungkapkan sesuatu yang akan diukur oleh kusioner itu, uji signifikan dilakukan dengan membandingkan nilai $r$ hitung dengan nilai $r$ table. Sedangkan uji reliabilitas dilakukan korelasi terhadap item pertanyaan yang dinyatakan valid. Uji ini digunakan untuk mengukur suatu kusioner yang merupakan indikator dari variabel atau kontruk. Suatu kusioner dikatakan reliabel atau handal jika jawaban seseorang terhadap perntanyaan adalah konsisten atau stabil dari waktu ke waktu. Untuk pengujian reliabilitas peneliti menggunakan alat ukur skala rentangan (seperti skala likert 1-5) yaitu croanbach's alpha > 0,60. diuji menggunakan bantuan komputer dengan program SPSS Versi22.

\section{6) Uji Asumsi Klasik}

a) Uji Normalitas

Sujarweni (2019:225) uji normalitas bertujuan untuk menguji apakah dalam model regresi variabel terikat $(X)$ dan variabel bebas $(Y)$ keduanya mempunyai distribusi normal ataukah tidak. Uji normalitas data dapat dilakukan dengan menggunakan uji Kolmogorow Smirnov satu arah. Pengambilan kesimpulan untuk menentukan apakah suatu data mengikuti distribusi normal atau tidak adalah dengan menilai signifikan. Jika 
signifikan > 0,05 maka variabel berdistribusic normal dan sebaliknya jika signifikan $<0,05$ maka variabel tidak berdistribusi normal.

\section{b) Uji Multikolinearitas}

Sujarweni

(2019:227)

menjelaskan bahwa uji multikolinieritas berarti ada hubungan linier yang sempurna atau pasti diantara beberapa semua variabel yang independen dari model yang ada. Akibat adanya multikolinieritas ini koefisien regresi tidak tertentu dan kesalahan standard tidak terhingga. Hal ini akan menimbulkan bias dalam spesifikasi. Uji multikolieritas bertujuan untuk menguji apakah pada model regresi ditemukan korelasi diantara variabel bebas.

Metode untuk menguji adanya multikolieritas ini dapat dilihat dari Tolerance Value Variance Inflantion Factor (VIF). Jika VIF > 10 atau jika tolerance value $<0,1$ maka terjadi multikolinearitas. Jika VIF $<10$ atau jika tolerance value $>0,1$ maka tidak terjadi multikolinearitas.

c) Uji Heteroskedastisitas

$$
\text { Ghozali (2013), }
$$

heteroskedastisitas bertujuan apakah dalam model regresi terjadi ketidaksamaan varians dari residual satu pengamatan ke pengamatan yang lain. Jika varians tetap maka disebut homoskedastisitas dan jika berbeda maka terjadi problem heteroskedastisitas. Model regresi yang baik yaitu homoskesdatisitas atau tidak terjadi heteroskedastisitas.

Untuk mendeteksi adanya heteroskedastisitas dilakukan dengan menggunakan teknik uji koefisien korelasi spearman's rho yaitu mengorelasikan variabel independen dengan residualnya. Kriteria pengujian dengan menggunakan tingkat signifikan 0,05 dengan uji 2 sisi. Jika korelasi antara variabel indenpenden dengan residualnya memberikan signifikan lebih dari 0,05, maka dapat dikatakan bahwa tidak terjadi problem heteroskedasitas.

\section{7) Teknik Analisis Data}

a) Analisis Regresi Linier Berganda Menurut Priyatno (2014:148) mengemukakan bahwa analisis regresi ini bertujuan untuk mengetahui pengaruh atau hubungan secara linier antara dua atau lebih variabel bebas dengan variabel terikat. Analisis regresi ini dinyatakan dengan persamaan sebagai berikut :

$$
Y^{\prime}=a+b 1 X 1+b 2 X 2+e
$$

b) Koefisien Korelasi

Siregar (2013:337) menjelaskan bahwa koefisien korelasi adalah bilangan yang menyatakan kekuatan hubungn antara dua variabel atau lebih, atau dapat menentukan arah hubungan dari kedua variabel. Nilai korelasi $(r)=(-10 \leq 1)$. untuk kekuatan hubungan, nilai koefisien korelasi berada di antara -1 sampai 1 , sedangkan untuk arah dinyatakan dalam bentuk positif (+) dan negatif (-). Apabila $r=-1$ korelasi negative sempurna, artinya terjadi hubungan bertolak belakang antara variabel $X$ dan variabel $Y$. Jika variabel $X$ naik, maka variabel $Y$ turun. Apabila $r=1$ korelasi positif sempurna, artinya terjadi hubungan searah variabel $x$ dan variabrl $Y$. Jika variabel $X$ naik, maka variabel $Y$ naik.

c) Koefisien Determinasi $\left(\mathrm{R}^{2}\right)$ Ghozali dalam Sujarweni (2019:228) menjelaskan bahwa koefisien determinasi yang dinotasikan dengan $R^{2}$ merupakan suatu ukuran yang penting dalam regresi. Determinasi $\left(R^{2}\right)$ mencerminkan kemampuan variabel dependen. Tujuan analisis ini adalah untuk menghitung besarnya pengaruh 
variabel independen terhadap variabel dependen. Nilai $R^{2}$ menunjukkan seberapa besar proporsi dari total variasi variabel tidak bebas yang dapat dijelaskan oleh variabel penjelasannya. Semakin tinggi nilai $R^{2}$ maka semakin besar proporsi dari total variasi variabel dependen yang dapat dijelaskan oleh variabel indepen. Nilai koefisien determinasi adalah antara nol (0) dan (1). Nilai $\mathrm{R}^{2}$ yang kecil berarti kemampuankemampuan variabel independent (bebas) dalam menjelaskan variasi variabel dependent sangat terbatas.

\section{8) Pengujian Hipotesis}

a) Uji t (Secara Parsial)

$$
\text { Sujarweni }
$$

(2019:229)

mengungkapkan uji $t$ menunjukan seberapa jauh pengaruh satu variabel independen atau variabel penjelas secar individu dalam menerangkan variabel dependen. Apabila nilai probabilitas signifikansinya lebih kecil dari 0,05 (5\%) maka suatu variabel independen berpengaruh signifikan terhadap variabel dependen. Hipotesis diterima jika taraf signifikan (a) $<0,05$ dan hipotesis ditolak jika tarif signifikan (a) $>0,05$.Kriterianya Jika $t<0,05$, maka Ho ditolak dan $\mathrm{Ha}$ diterima dan Jika $\mathrm{t}>0,05$, maka $\mathrm{Ho}$ diterima dan $\mathrm{Ha}$ ditolak.

\section{b) Uji F (Secara Simultan) Sujarweni}

(2019:228)

menjelaskan bahwa signifikan model regresi secara simultan diuji dengan melihat nilai signifikan (sig) dimana jika nilai sig dibawah 0,05 maka variabel bebas (independent) berpengaruh terhadap variable terikat (dependen). Uji F-statistik digunakan untuk membuktikan ada pengaruh antara variabel bebas (independent) terhadap variabel terikat (dependen) secara simultan. Adapun kriteria jika $f<0,05$, maka Ho di tolak dan Ha diterima dan jika $f>0,05$, maka Ho diterima dan Haditolak.

\section{HASIL PENELITIAN \\ 1) Pengujian Instrumen}

a) Uji Validitas

Untuk menguji validitas kuesioner dalam penelitian ini digunakan rumus korelasi product moment yang dilakukan terhadap 34 responden. Analisis validitas kuesioner meliputi variabel tanggung jawab $\left(\mathrm{X}_{1}\right)$, loyalitas kerja (X2), dan kinerja (Y).

Berdasarkan hasil perhitungan untuk ketiga variabel dari 10 butir pertanyaan dipereroleh nilai $r$ hitung untuk variabel tangungu jawab(X1) semua valid kecuali butir pertanyaan nomor 4. tidak valid karena $r$ hitung lebih kecil dari $r$ tabel.Untuk variabel loyalitas (X2) semuanya valid karena $r$ hitung lebih besar dari $r$ tabel. Sedangkan untuk variabel kinarja karyawan $(\mathrm{Y})$ semuanya valid kecuali butir pertanyaan nomor $6,7,8$ dan tidak valid karena $r$ hitung lebih kecil dari $r$ tabel. Dengan demikian untuk penelitian selanjurnya variabel tanggungjawab menggunakan 9 butir pertanyaan, loyalitas menggunakan 12 butir pertanyaan dan kinerja karyawan menggunakan 7 butir pertanyaan.

b) Uji Reliabilitas

Uji reliabilitas adalah tingkatan pada mana suatu tes secara koefisien mengukur berapapun hasil pengukuran itu. Reliabilitas dinyatakan dengan angka-angka (biasanya sebagai suatu koefisien), koefisien yang tinggi menunjukkan reliabilitas yang tinggi. Hasil uji reliabilitas dalam penelitian ini menggunakan koefisien Cronbach Alpha, di mana instrumen dikatakan reliabel jika memiliki koefisien Cronbach Alpha > 0.60. Hasil uji reliabilitas data dapat dilihat pada tabel berikut: 
Tabel Hasil Uji Reliabilitas

\begin{tabular}{|c|c|c|c|}
\hline No & Variabel & Cronbabch Alpha & Keterangan \\
\hline 1 & Tanggung Jawab & 0,725 & Reliabel \\
\hline 2 & Loyalitas kerja & 0,876 & Reliabel \\
\hline 3 & Kinerja & 0,633 & Reliabel \\
\hline
\end{tabular}

Sumber: Data primer yang diolah, 2020

Hasil uji reliabilitas tersebut menunjukkan bahwa semua variabel mempunyai koefisien cronbach alpha yang besar, yaitu diatas 0,60 sehingga dapat disimpulkan bahwa item-item pengukur variabel dari kuesioner adalah reliabel yang berarti bahwa kuesioner yang digunakan dalam penelitian ini merupakan kuesioner yang handal.

\section{2) Uji Asumsi Klasik}

a) Uji Normalitas

Dalam penelitian ini untuk menguji normalitas data penulis menggunakan teknik one sample Kolmogorov-Smirnov Test.

Tabel One-Sample Kolmogorov-Smirnov Test

\begin{tabular}{|llr|}
\hline \multicolumn{2}{|l|}{ Unstandardized Residual } & \\
\hline $\mathrm{N}$ & & 34 \\
\hline Normal Parameters a,b & Mean & 0,0000000 \\
& Std. Deviation & 2,09994183 \\
\cline { 2 - 3 } Most Extreme Differences & Absolute & 0,120 \\
\cline { 2 - 3 } & Positive & 0,120 \\
\cline { 2 - 3 } & Negative & $-0,096$ \\
\hline Test Statistic & 0,120 \\
\hline \multicolumn{1}{|l}{ Asymp. Sig. (2-tailed) } & & $.200 \mathrm{c}, \mathrm{d}$ \\
\hline a. Test distribution isNormal. & \\
b. Calculated fromdata. & \\
c. Lilliefors SignificanceCorrection. & \\
d. This is a lower bound of the truesignificance. & \\
\hline
\end{tabular}

\section{Sumber: Data primer yang diolah, 2020}

Berdasarkan hasil uji normalitas data menggunakan One Sample Kolmogorov Smirnov Test, sebagaimana tersaji pada tabel diatas dapat disimpulkan bahwa variabel memiliki data normal, hal tersebut dikarenakan data tersebut memiliki Asymp. Sig > (a) 0,05. b) Uji Multikolinearitas

Metode untuk menguji adanya multikolinearitas ini dapat dilihat dari Tolerance Value Variance Inflantion Factor (VIF). Jika VIF > 10 atau jika tolerance value $<0,1$ maka terjadi multikolinearitas. Jika VIF $<10$ atau jika tolerance value $>0,1$ maka tidak terjadi multikolinearitas. 
Tabel Hasil Uji Multikolinearitas

\begin{tabular}{|c|l|c|c|}
\hline Model & \multicolumn{2}{|c|}{ Collinearity Statistics } & \multirow{2}{*}{ Keterangan } \\
\hline Constant & Tolerance & VIF & Tidak ada Multikolinearitas \\
\hline Tanggung jawab & 0,812 & 1,231 & Tidak ada Multikolinearitas \\
\hline Loyalitas kerja & 0,812 & 1,231 & Tidak ada \\
\hline
\end{tabular}

Sumber: Data primer yang diolah, 2020

Pada tabel tersebut menunjukkan semua angka VIF variabel model regresi lebih kecil dari 10 (VIF < 10), hal ini menunjukkan model regresi linier berganda tidak mempunyai persoalan multikolinearitas. Hasil perhitungan nilai tolerance juga menunjukkan tidak ada varibel independen yang nilainya kurang dari 0,1 (tolerance $>0,1$ ), yang berarti tidak ada korelasi antar variabel independen yang nilainya lebih dari $95 \%$, hal ini berarti tidak terjadi multikolinearitas. c) Uji Heteroskedasitas

Untuk mendeteksi adanya heteroskedastisitas dilakukan dengan menggunakan teknik uji koefisien korelasi spearman's rho yaitu mengorelasikan variabel independen dengan residualnya. Kriteria pengujian dengan menggunakan tingkat signifikan 0,05 dengan uji 2 sisi. Jika korelasi antara variabel indenpenden dengan residualnya memberikan signifikan lebih dari 0,05 , maka dapat dikatakan bahwa tidak terjadi problem heteroskedasitas.

Tabel Hasil Uji Heteroskedasitas

Correlations

\begin{tabular}{|c|c|c|c|c|c|}
\hline & & & $\begin{array}{c}\text { Tanggung } \\
\text { Jawab }\end{array}$ & Loyalitas & $\begin{array}{c}\text { Unstandardize } \\
\text { d Residual }\end{array}$ \\
\hline Spearman's rho & Tanggung Jawa & $\begin{array}{l}\text { Correlation } \\
\text { Coefficient }\end{array}$ & 1,000 & $.454^{* *}$ & 0,008 \\
\hline & & Sig. (2-tailed) & & 0,007 & 0,963 \\
\hline & & $\mathrm{N}$ & 34 & 34 & 34 \\
\hline & Loyalitas & $\begin{array}{l}\text { Correlation } \\
\text { Coefficient }\end{array}$ & $.454^{* *}$ & 1,000 & 0,068 \\
\hline & & Sig. (2-tailed) & 0,007 & & 0,703 \\
\hline & & $\mathrm{N}$ & 34 & 34 & 34 \\
\hline & $\begin{array}{l}\text { Unstandardized } \\
\text { Residual }\end{array}$ & $\begin{array}{l}\text { Correlation } \\
\text { Coefficient }\end{array}$ & 0,008 & 0,068 & 1,000 \\
\hline & & Sig. (2-tailed) & 0,963 & 0,703 & \\
\hline & & $\mathrm{N}$ & 34 & 34 & 34 \\
\hline
\end{tabular}

**. Correlation is significant at the 0.01 level (2-tailed).

Sumber: Data primer yang diolah, 2020

Berdasarkan hasil uji heteroskedastisitas dengan menggunakan uji koefisien korelasi spearman's rho dapat dilihat bahwa korelasi antara variabel bebas (tanggungjawab dan loyalitas) dengan unstandardized residual memiliki nilai signifikan lebih besar dari 0,05. Karena signifikansi lebih besar daripada 0,05 , maka dapat disimpulkan bahwa tidak terjadi problem heteroskedasitas.

\section{3) Uji Regresi Linier Berganda}

Sugiyono (2018:275) uji regresi ganda digunakan oleh peneliti, bila peneliti bermaksud meramalkan bagaimana keadaan (naik turunnya) variabel dependen (kriterium), bila dua 
atau lebih variabel independen sebagai faktor prediktor dimanipulasi (dinaikturunkan nilainya). Jadi analisis regresi ganda akan dilakukan bila jumlah variabel independennya minimal 2. Proses pengolahan data dilakukan dengan menggunakan program Statistical Package for the Social Science (SPSS) versi 22.0. Adapun hasil regresi linier berganda tersebut disajikan pada berikut ini.

Tabel Hasil Uji Regresi Berganda

\begin{tabular}{|c|c|c|c|c|c|}
\hline \multicolumn{6}{|c|}{ Coefficients $^{a}$} \\
\hline \multirow[b]{2}{*}{ Model } & \multicolumn{2}{|c|}{$\begin{array}{c}\text { Unstandardized } \\
\text { Coefficients }\end{array}$} & \multirow{2}{*}{\begin{tabular}{|c|}
$\begin{array}{c}\text { Standardized } \\
\text { Coefficients }\end{array}$ \\
Beta
\end{tabular}} & \multirow[b]{2}{*}{$\mathbf{t}$} & \multirow[b]{2}{*}{ Sig. } \\
\hline & $B$ & Std. Error & & & \\
\hline (Constant) & 16,888 & 4,316 & & 3,913 & 0,000 \\
\hline Tanggung Jawab & 0,250 & 0,114 & 0,382 & 2,188 & 0,036 \\
\hline Loyalitas & 0,069 & 0,071 & 0,169 & 0,968 & 0,341 \\
\hline
\end{tabular}

a. Dependent Variable: Kinerja

Sumber: Data primer yang diolah, 2020

Dari hasil perhitungan tabel coefficients diatas, di dapat hasil regresi linier berganda yaitu nilai kofisien regresi untuk tanggungjawab (X1) sebesar 0,250 dan nilai kofisien regresi untu loyalitas ( X2) sebesar 0,069 dan nilai konstan sebesar 16,888. Berdasarkan tabel 6, dapat dibuat persamaan regresi linier berganda sepertiberikut:

$Y=16,888+0,250 X_{1}+0,069 X_{2}$ a) Uji Korelasi dan Koefisien Determinasi $\left(\mathrm{R}^{2}\right)$ Berganda

Uji korelasi ganda adalah suatu nilai yang memberikan kuatnya pengaruh atau hubungan dua variabel atau lebih secara bersama-sama dengan variabel lain. Sedangkan koefisien determinasi digunakan untuk mengetahui seberapa besar pengaruh variabel-variabel bebas memiliki pengaruh terhadap variabel terikatnya. Pengujian ini diuji dengan bantuan komputer dengan program SPSS Versi 22, dengan output sebagaiberikut:

Tabel Hasil Uji Korelasi dan Determinasi

Model Summary ${ }^{b}$

\begin{tabular}{|c|rr|r|c|c|}
\hline Model & R & R Square & $\begin{array}{c}\text { Adjusted R } \\
\text { Square }\end{array}$ & $\begin{array}{c}\text { Std. Error of } \\
\text { the Estimate }\end{array}$ \\
\hline 1 & & $.480 \mathrm{a}$ & 0,231 & 0,181 & 2,01650 \\
\hline
\end{tabular}

a.Predictors: (Constant), Loyalitas, TanggungJawab

b.Dependent Variable:Kinerja

Sumber: Data primer yang diolah, 2020

Berdasarkan tabel di atas diperoleh nilai $\mathrm{R}$ sebesar $0,480^{\mathrm{a}}$ ini

menunjukkan bahwa nilai $R$ berada pada hubungan atau keeratan yang 
sangat kuat. Maka dapat disimpulkan bahwa variabel tanggungjawab dan loyalitas terdapat hubungan yang signifikan terhadap kinerja karyawan. Untuk koefisien determinasi (adjusted $R^{2}$ ) dari hasil perhitungan dengan menggunakan program SPSS versi 22 dapat diketahui bahwa diperoleh nilai sebesar 0,181 sehingga dalam penelitian ini tanggungjawab dan loyalitas dapat mempengaruhi kinerja karyawan $18 \%$, sedangkan sisanya dipengaruhi oleh variabel-variabel lainnya yang tidak diteliti dalam penelitianini.

b) Pengujian Hipotesis
1) Hasil Uji $F$

Uji $F$ digunakan untuk mengetahui pengaruh variabel bebas (tanggungjawab dan loyalitas) secara serentak atau simultan terhadap variabel terikat (kinerja karyawan). Uji $F$ ditujukan untuk mengukur tingkat keberartian hubungan secara keseluruhan koefisien regresi dari variabel bebas terhadap variabel terikat dengan menentukan nilai uji $F$ dengan tabel ANOVA (analysis of variance) dan tingkat signifikansi. Hasil pengujian tersebut adalah sebagai berikut:

Tabel Hasil Uji F (Simultan)

ANOVA $^{a}$

\begin{tabular}{|c|c|c|c|c|c|}
\hline Model & $\begin{array}{l}\text { Sum of } \\
\text { Squares }\end{array}$ & df & $\begin{array}{l}\text { Mean } \\
\text { Square }\end{array}$ & $\mathrm{F}$ & Sig. \\
\hline Regression & 37,828 & 2 & \multicolumn{2}{|c|}{$18,9144,651$} & $.017^{b}$ \\
\hline Residual & 126,054 & 31 & 4,066 & & \\
\hline Total & 163,882 & 33 & & & \\
\hline
\end{tabular}

a.Dependent Variable:Kinerja

b.Predictors: (Constant), Loyalitas, TanggungJawab

Sumber: Data primer yang diolah, 2020

Pengujian secara simultan menunjukkan bahwa nilai $F$ untuk model regresi adalah 4,651 dengan tingkat signifikansi 0,000 $<0,05$ maka tingkat signifikansi model regresi lebih kecil dari tarif nyata. Hasil ini menunjukkan bahwa variabel bebas yaitu tanggungjawab dan loyalitas secara simultan mempunyai pengaruh yang signifikan terhadap variabel terikat yaitu kinerja karyawan.
2) Hasil Uji t

Uji parsial (uji-t) dilakukan untuk menguji signifikansi pengaruh variabel-variabel bebas (insentif dan pengawasan) secara individual terhadap variabel terikat (produktivitas kerja karyawan) pada Wisma Grand Kemala Palembang. Uji-t dalam penelitian ini digunakan untuk melakukan pengujian hipotesis dengan tingkat signifikansi $\quad(\alpha=0,05)$. Uji-t ditunjukkan pada tabel berikut ini: 
Tabel Hasil Uji T (Parsial)

Coefficientsa

\begin{tabular}{|c|r|r|r|r|r|}
\hline \multirow{2}{*}{ Model } & \multicolumn{4}{|c|}{ Standardized } & \\
& Unstandardized Coefficients & Coefficients & & \\
& \multicolumn{1}{|c|}{$\mathrm{B}$} & Std. Error & Beta & $\mathrm{t}$ & Sig. \\
\hline (Constant) & 16,888 & 4,316 & & 3,913 & 0,000 \\
\hline Tanggung Jawab & 0,250 & 0,114 & 0,382 & 2,188 & 0,036 \\
\hline Loyalitas & 0,069 & 0,071 & 0,169 & 0,968 & 0,341 \\
\hline
\end{tabular}

a. Dependent Variable: Kinerja

Sumber: Data primer yang diolah, 2020

Berdasarkan hasil uji t pada tabel diatas maka diperoleh pengujian hipotesis dalam penelitian ini yaitu sebagai berikut :

$\checkmark \quad$ Uji Hipotesis Pertama

$\mathrm{H} 1$ : Ada pengaruh tanggungjawa terhadap kinerja karyawan pada Wisma Grand Kemala Palembang.

Berdasarkan tabel Hasil Uji T (Parsial) menunjukkan bahwa nilai $t$ sebesar 2,188 dengan signifikansi $0,036<0,05$. Hasil penelitian ini membuktikan kebenaran hipotesis 1 (satu) atau tanggungjawab berpengaruh positif signifikan terhadap kinerja karyawan pada Wisma Grend KemalaPalembang.

$\checkmark \quad$ Uji Hipotesis Kedua

$\mathrm{H} 2$ : Ada pengaruh loyalitas terhadap kinerja karyawan padaWisma Grend Kemala Palembang.

Berdasarkan tabel Hasil Uji T (Parsial) menunjukkan bahwa nilai $t$ sebesar 0,968 dengan signifikansi $0,341<0,05$. Hasil penelitian ini membuktikan kebenaran hipotesis 2 (dua) atau loyalitas berpengaruh positif signifikan terhadap kinerja karyawan pada Wisma Grand Kemala Palembang.

\section{E. PEMBAHASAN}

1) Pengaruh Tanggung jawab dan

\section{Loyalitas kerja terhadap Kinerja}

Berdasarkan hasil uji $\mathrm{F}$ diperoleh nilai $F$ untuk model regresi adalah 4,651 dengan tingkat signifikansi 0,000 $<0,05$ maka tingkat signifikansi model regresi lebih kecil dari taraf nyata. Hasil ini menunjukkan bahwa variabel bebas yaitu tanggung jawab dan loyalitas kerja secara simultan mempunyai pengaruh yang signifikan terhadap variabel terikat yaitu kinerja karyawan. Selain itu, nilai Fhitung sebesar 4,651 lebih besar dibandingkan dengan nilai Ftabel sebesar 3,290.

Pengaruh secara serempak antara variabel bebas dan variabel terikat memberikan informasi yang kuat yaitu dibuktikan dengan koefisien determinasi (Adjusted $R^{2}$ ). Koefisien determinasi (Adjusted $R^{2}$ ) pada intinya menerangkan sebanyak mungkin variasi dalam variabel terikat dengan menggunakan variabel bebas dalam model. Suatu model dikatakan baik jika diukur dengan menggunakan nilai Adjusted $R^{2}$ yang setinggi mungkin.Nilaikoefisien determinasi adalah antara nol (0) dan satu (1). Nilai $\mathrm{R}^{2}$ yang kecil berarti kemampuan variabel-variabel independen (variabel bebas) dalam menjelaskan variasi variabel dependen amat terbatas. Nilai yang mendekati satu berarti variabelvariabel independen memberikan 
hampir semua informasi yang dibutuhkan untuk memprediksi variasi variabel dependen.

Hasil koefisien determinasi diperoleh nilai adjusted $R 2$ sebesar 0,480 atau $48 \%$. Hasil penelitian ini berarti bahwa $48 \%$ variasi variabel terikat yaitu kinerja karyawan dipengaruhi oleh variasi variabel bebas yaitu tanggung jawab dan loyalitas kerja, sedangkan sisanya $32 \%$ dipengaruhi oleh faktor lainnya yang tidak dimasukkan ke dalam model tersebut. Pembahasan berdasarkan perhitungan analisis dapat dinyatakan bahwa pengaruh tanggung jawa dan loyalitas kerja terhadap kinerja karyawan pada Wisma Grand Kemala Palembang adalah signifikan.

Hasil uji asumsi klasik juga membuktikan bahwa model regresi memenuhi persyaratan karena terbukti data-data yang digunakan dalam analisis berdistribusi normal dan tidak terjadi gejala multikolinearitas dan heteroskedastisitas (hasil pada pembahasan uji asumsi klasik). Berdasarkan analisis penelitian ini maka yang berpengaruh secara nyata terhadap kinerja karyawan yaitu tanggung jawab (X1) berpengaruh positif signifikan, dan loyalitas kerja (X2) berpengaruh positif signifikan.

\section{2) Pengaruh Tanggung jawa terhadap Kinerja}

Dari hasil regresi dapat dijelaskan bahwa variabel bebas tanggung jawab berpengaruhsignifikan terhadap variabel terikat Kinerja, variabel tanggung jawab menunjukkan hasil yang positif, artinya tinggi rendahnya tanggung jawab akan berbanding lurus atau diikuti dengan tinggi rendahnya kinerja karyawan Wisma Grand Kemala. Hal ini didukung oleh hasil uji $t$ dengan tingkat signifikansi 0,036 (signifikan < $0,05)$. Yang artinya kenaikan tanggung jawab menyebabkan perubahan kinerja. Dengan demikian jika tingkat tanggung jawab dinaikkan maka akan berpengaruh atau dengan kata lain akan meningkatkan kinerja karyawan

Hasil penelitian ini sejalan dengan teori Hasibuan (2014:183), Tanggung jawab adalah keharusan untuk melakukan semua kewajiban atau tugas-tugas yang dibebankan kepadanya sebagai akibat dari wewenang yang diterima atau dimilikinya.Dengan bertanggung jawab dalam bekerja dapat memberikan hasil yang efektif. Hasil penelitian ini juga diperkuat oleh hasil penelitian terdahulu yang dilakukan oleh Nurdin Yusuf (2018) yang menunjukkan bahwa tanggungjawab berpengaruh signifikan terhadap peningkatan kinarjapegawai.

\section{3) Pengaruh Loyalitas Kerja Terhadap Kinerja}

Berdasarkan hasil penelitian loyalitas berpengaruh terhadap kinerja karyawan. Hal ini ditunjukkan dengan nilai $\beta=0,069$, hal ini dapat diartikan bahwa jika loyalitas meningkat maka kinerja karyawan akan meningkat positif. Hasil pengujian hipotesis menunjukkan bahwa nilai thitung untuk loyalitas adalah 0,968 dengan signifikansinya sebesar 0,001, sedangkan pada taraf signifikansi sebesar 0,05 dengan df sebesar $=34$ diperoleh nilai ttabel sebesar 3,290 sehingga nilai thitung $(4,651)>$ nilai ttabel (3,290). Dengan demikian menunjukkan bahwa ada pengaruh loyalitas terhadap kinerja karyawan pada Wisma Grand Kemala Palembang. Kesimpulannya yaitu bahwa Ho ditolak dan $\mathrm{Ha}$ diterima, artinya ada pengaruh loyalitas terhadap kinerja karyawan pada Wisma Grand Kemala Palembang dapat diterima.

Hasil yang diperoleh diperkuat 
oleh penelitian yang dilakukan oleh Annecia Marchhlleh Soegandhni dkk (2013) Hasil penelitian menunjukkan bahwa ada pengaruh positif loyalitas terhadap Otganizazitional Citizenship Behavior. Hal ini berarti semakin baikloyalitas, maka semakin tinggi kinerja karyawan, sebaliknya semakin kurang baik loyalitas, maka semakin rendah kinerja karyawan. Loaylitas yang efektif akan meningkatkan kemampuan dan hasil kerja serta semangat kerja yang tinggi dari karyawan sehingga karyawan tersebut ingin mengembangkan dirinya agar menjadi karyawan yang lebih bermutu dan efisien. Dengan menciptakan loyalitas yang efektif akan meningkatkan kinerjakaryawan.

\section{F. KESIMPULAN DANSARAN}

1) Kesimpulan

Berdasarkan hasil penelitian serta hasil analisis data dan pembahasan yang telah diuraikan sebelumnya, maka dapat diambil kesimpulan hasil penelitian sebagai berikut:

a) Secara bersama-sama tanggung jawab dan loyalitas kerja memiliki pengaruh yang signifikan terhadap kinerja karyawan pada Wisma

Grand KemalaPalembang.

b) Secara parsial tanggung jawab memiliki pengaruh yang signifikan terhadap kinerja karyawan pada Wisma Grand KemalaPalembang.

c) Secara parsial loyalitas kerja memiliki pengaruh yang signifikan terhadap kinerja karyawan pada Wisma Grand Kemala Palembang.

\section{2) Saran}

Sehubungan dengan hasil penelitian yang telah disimpulkan di atas, peneliti merumuskan beberapa saran pada pihak Wisma Grand
Kemala sebagai berikut :

a) Untuk meningkatkan kinerja karyawan, pengetahuan dan keahlian tanggung jawab karyawan secara berkelanjutan sebaiknya Wisma Grand Kemala selalu memberikan pemahaman kerja kepada karyawannya agar hasil kinerjameningkat.

b) Pihak perusahaan sebaiknya melakukan penilaian hal apa saja yang perlu dilakukan untuk meningkatkan kinerja, sehingga tujuan kedua belah pihak baik perusahaan maupun karyawan dapat tercapai denganbaik.

c) Bagi peneliti yang akan akan meneliti pada permasalahan yang sejenis, diharapkan memasukkan variabel lain di luar variabel yang sudah ada dalam penelitian ini.

\section{DAFTAR PUSTAKA}

Fahmi, Irham, 2013. Manajemen Strategi. Bandung: Alfabeta, CV.

2016.

Pengantar

Manajemen Sumber daya Manusia Konsep \& Kinerja. Jakarta: Mitra Wacana Media.

Ghozali, Imam. 2013. Aplikasi Analisis Multivriate dengan Program SPSS. Semarang: Badan Penerbit Universitas Dipenogoro.

Hasibuan, Malayu S.P. 2014. Manajemen Sumber Daya Manusia. Jakarta: PT. Bumi Aksara.

Hasibuan, Malayu S.P.2016. Manajemen Dasar, Pengertian, dan Masalah. Jakarta: PT.Bumi Aksara. 
Oktariansyah. 2020. Pengaruh Karakteristik Individual dan Lingkungan Kerja Terhadap Kinerja Pegawai Kantor Dinas Transmigrasi Kabupaten Banyuasin. Jurnal Media Wahana Ekonomika, Vol 17 No. 2 Juli 2020, Hal: 164-178.

Pranita, N. M. 2016. Jurnal Skripsi. Pengaruh Loyalitas Pegawai Terhadap Kinerja Lembaga Perkreditan Desa (Studi Kasus LPD Desa Kedongan), Fakultas IImu Sosial dan IImu Politik Universitas Udayana.

Priyatno. 2014. Pengelola Data Terpraktis SPSS 22. Yogyakarta: Andi.

Sinambela, Lijan, Poltak, 2016. Manajemen Sumber Daya Manusi. Jakarta: PT Bumi Aksara.

Siregar. 2013. Metode Penelitian Kuantitatif. Jakarta: PT. Fajar Interpratama Mandiri.

Soegandhi,V.M.dkk, 2013. Jurnal Skripsi. Pengaruh Kepuasan
Kerja dan Loyalitas Kerja Terhadap Organizational Citizenship Behavior Pada Karyawan PT. Surya Timur Sakti Jatim , Fakultas Manajemen Universitas Kristen Petra.

Sugiyono, 2018. Metode Penelitian Manajemen. Bandung : Alfabeta.

Sujarweni, V, Wiratna, 2019. Metode Penelitian Bisnis dan Ekonomi. Yogyakarta: Pustaka Baru Press.

Wibowo, 2016. Manajemen Kinerja. Jakarta: PT Raja Gravindo Persada.

Wibowo. 2014. Manajemen Kinerja. Jakarta: PT. Rajagrofindo Persada.

Widodo, Suparno Eko. 2015. Manajemen Pengembangan Sumber Daya Manusia. Yogyakarta: Pustaka Pelajar

Yusuf, Muhammad Yasir.2017. Manajemen Corporate Social Responslibility (I-CSR) Depok : kencana 